DOI https://doi.org/10.30525/978-9934-26-038-4-62

\title{
ВПРОВАДЖЕННЯ ЕКОЛОГО-ГІГІСНІЧНОЇ КОНЦЕПЦІЇ З ОХОРОНИ ЗДОРОВ'Я НАСЕЛЕННЯ НА ВОДНИХ РЕКРЕАЦІЙНИХ В ХАРКІВСЬКОЇ ОБЛАСТІ
}

\author{
Литвиненко М. I. \\ кандидат медичних наук, \\ доиент кафедри клінічної лабораторної діагностики \\ Харківський національний медичний університет \\ м. Харків, Украӥна \\ Литвиненко Г. Л. \\ кандидат медичних наук, \\ дочент кафедри клінічної лабораторної діагностики \\ Національний фармацевтичний університет \\ м. Харків, Украӥна
}

В організації відпочинку особлива роль належить водним об'єктам на свіжому повітрі. Це набуває особливої важливості в період пандемії COVID-19. Можливість займатися різноманітними видами спорту, мікрокліматичний комфорт, естетична дія берегових мальовничих ландшафтів, зміна вражень - все це, взагалі у комплексі, сприяє тому, що водойми цілком можна вважати природними лікувальницями. Ось чому більша частина рекреаційних закладів розміщуються безпосередньо на берегах водойм або поблизу них [1].

На сьогоднішній день проблема охорони джерел рекреаційного водокористування, поліпшення якості води і охорони здоров'я населення в Україні є надзвичайно актуальною. Тому, принциповим вектором політики України, щодо оздоровлення рекреаційних водойм та забезпечення населення водою гарантованої якості 3 поверхневих джерел водопостачання $є$ басейновий принцип та транскордонне співробітництво, яке зосереджується на двох організаційних засадах: регіональному багатосторонньому рівні та транскордонному двосторонньому рівні [2].

Найпопулярніші у населення водні рекреації, пов'язані з морськими купаннями. Однак, як показує досвід багаторічних комплексних фізіотерапевтичних спостережень, відпочинок біля моря в спекотні літні місяці корисний далеко не всім, а в основному практично здоровим людям молодого і середнього віку. Людям 3 порушеним здоров'ям, особливо літнім, краще відпочивати в умовах звичного для них клімату [3]. 
Фахівці різних профілів відмічають, що в частині рекреаційних зон в Харківської області не в повному обсязі проведені роботи щодо очищення водоймищ та підготовки пляжів; відсутній акт обстеження дна акваторії пляжу водолазною службою; відсутні лабораторних досліджень води з водойм та піску тощо $[4,5,6]$.

На основі системного аналізу та узагальнення результатів досліджень 3 оцінки санітарно-екологічного стану рекреаційних водойм Харківської області, визначення недоліків в організаційному забезпеченні проблеми використання поверхневих водойм як зони рекреації, оцінки ступеня медико-екологічної напруги в районі розташування водних рекреаційних зон фахівцями вищої школи Харківщини науково обгрунтовано та розроблено еколого-гігієнічну концепцію з охорони здоров'я населення на водних рекреаційних зонах пріоритетновизначальними принципами якої $є$ підвищення ефективності оздоровлення населення на рекреаційних водоймах та запобігання антропогенному навантаженню на зони рекреації водних об'єктів [7].

Таблиця 1

\begin{tabular}{|c|c|c|c|}
\hline \multicolumn{4}{|c|}{ Мета Концепції } \\
\hline \multicolumn{4}{|c|}{$\begin{array}{l}\text { Підвищення ефективності оздоровлення населення на рекреаційних } \\
\text { водоймах та запобігання антропогенному навантаженню на зони } \\
\text { рекреації водних об’єктів }\end{array}$} \\
\hline \multicolumn{4}{|c|}{ Актуальність розроблення Концепції } \\
\hline $\begin{array}{l}\text { Відсутність } \\
\text { в обласних } \\
\text { програмах } \\
\text { чітких } \\
\text { рішень } \\
\text { з оптимізації } \\
\text { умов оздо- } \\
\text { ровлення } \\
\text { та масового } \\
\text { відпочинку } \\
\text { населення } \\
\text { на воді }\end{array}$ & $\begin{array}{l}\text { Відсутність в регіоні } \\
\text { офіційної адміністра- } \\
\text { тивної структури } \\
\text { з організації та конт- } \\
\text { ролю за умовами оздо- } \\
\text { ровлення й масового } \\
\text { відпочинку населення } \\
\text { на воді }\end{array}$ & $\begin{array}{l}\text { Втрата } \\
\text { природної } \\
\text { чистоти та } \\
\text { придатності } \\
\text { до самоочи- } \\
\text { щення } \\
\text { водних } \\
\text { об'єктів } \\
\text { регіону }\end{array}$ & $\begin{array}{l}\text { Незадовіль- } \\
\text { ний санітар- } \\
\text { ний стан зон } \\
\text { рекреацій } \\
\text { водних } \\
\text { об'єктів } \\
\text { (пляжів) }\end{array}$ \\
\hline \multicolumn{4}{|c|}{ Завдання Концепції } \\
\hline \multicolumn{4}{|c|}{$\begin{array}{l}\text { Стабілізація санітарно-екологічного стану рекреаційних водойм } \\
\text { та оптимізація умов масового відпочинку населення на них шляхом } \\
\text { рішення проблеми відповідності якості води рекреаційних водойм } \\
\text { гігієнічним вимогам та благоустрою рекреаційних зон }\end{array}$} \\
\hline
\end{tabular}


Продовження таблиці 1

\begin{tabular}{|c|c|c|c|}
\hline \multicolumn{4}{|c|}{ Заходи Концепції } \\
\hline $\begin{array}{l}\text { Підготовка } \\
\text { комплексної } \\
\text { програми } \\
\text { розвитку } \\
\text { рекреацій- } \\
\text { ного водо- } \\
\text { господарст- } \\
\text { ва Харківсь- } \\
\text { кої області } \\
\text { на період до } \\
2021 \text { року }\end{array}$ & $\begin{array}{l}\text { Відновлення умов } \\
\text { життєдіяльності } \\
\text { водно-рекреаційних } \\
\text { екосистем. } \\
\text { Поліпшення санітар- } \\
\text { ного стану водних } \\
\text { об'єктів }\end{array}$ & $\begin{array}{l}\text { Виконання } \\
\text { заходів із } \\
\text { щорічної } \\
\text { підготовки } \\
\text { пляжів до } \\
\text { купальних } \\
\text { сезонів на } \\
\text { підставі прове- } \\
\text { дення держав- } \\
\text { ного та гро- } \\
\text { мадського } \\
\text { контролю }\end{array}$ & $\begin{array}{l}\text { Забезпе- } \\
\text { чення } \\
\text { санітарної та } \\
\text { екологічної } \\
\text { безпеки під } \\
\text { час викори- } \\
\text { стання } \\
\text { водних } \\
\text { рекреацій }\end{array}$ \\
\hline \multicolumn{4}{|c|}{ Організація виконання заходів Концепції } \\
\hline $\begin{array}{l}\text { Створення } \\
\text { робочої групи } \\
\text { під керів- } \\
\text { ництвом облас- } \\
\text { ної державної } \\
\text { адміністрації } 3 \\
\text { питань контро- } \\
\text { лю за водними } \\
\text { рекреаційними } \\
\text { зонами регіону }\end{array}$ & $\begin{array}{l}\text { Щотижнева нау- } \\
\text { ково-пізнавальна } \\
\text { програма щодо } \\
\text { вимог до оздо- } \\
\text { ровлення та масо- } \\
\text { вого відпочинку } \\
\text { населення на воді } \\
\text { в ефірі одного } 3 \\
\text { регіональних } \\
\text { каналів }\end{array}$ & $\begin{array}{l}\text { Програма еко- } \\
\text { логічної освіти } \\
\text { серед учнів } \\
\text { загально- } \\
\text { освітніх нав- } \\
\text { чальних } \\
\text { закладів та } \\
\text { студентів ви- } \\
\text { щих навчаль- } \\
\text { них закладів }\end{array}$ & $\begin{array}{l}\text { Підготовка } \\
\text { «Пам’яток» } \\
3 \text { питань } \\
\text { екологіч- } \\
\text { ного вихо- } \\
\text { вання для } \\
\text { населення }\end{array}$ \\
\hline \multicolumn{4}{|c|}{ Очікувані результати від виконання заходів Концепції } \\
\hline $\begin{array}{l}\text { Упровадження } \\
\text { регіональної } \\
\text { системи } \\
\text { організації та } \\
\text { контролю умов } \\
\text { оздоровлення } \\
\text { й масового } \\
\text { відпочинку } \\
\text { населення на } \\
\text { рекреаційних } \\
\text { водоймах }\end{array}$ & $\begin{array}{l}\text { Забезпечення } \\
\text { притоку інве- } \\
\text { стицій до } \\
\text { регіону в ро- } \\
\text { зрізі утворення } \\
\text { екологічно } \\
\text { безпечної } \\
\text { туристичної } \\
\text { інфра- } \\
\text { структури } \\
\text { сходу України }\end{array}$ & $\begin{array}{l}\text { Поліпшення } \\
\text { стану питного } \\
\text { водопостачання } \\
\text { районів та міст } \\
\text { області, які отри- } \\
\text { мують питну воду } \\
\text { з поверхневих } \\
\text { джерел }\end{array}$ & $\begin{array}{l}\text { Запрова- } \\
\text { дження } \\
\text { нової систе- } \\
\text { ми інфор- } \\
\text { мування } \\
\text { про стан } \\
\text { функціону- } \\
\text { вання } \\
\text { водних } \\
\text { рекреацій }\end{array}$ \\
\hline
\end{tabular}

На теперішній час здійснюється впровадження зазначеної концепції. Реалізація розробленої еколого-гігієнічної концепції в Харківській області буде сприяти підвищенню ефективності оздоровлення населення на рекреаційних водоймах регіону та покращенню соціальних аспектів, що створить умови для стабілізації функціонування регіону у цілому. 


\section{Література:}

1. Фоменко Н.В. Рекреаційні ресурси та курортологія / Н.В. Фоменко - К. : Центр навчальної літератури, 2007. - 312 с.

2. Андрусяк Н.С. Загальні підходи до оцінки водних ресурсів з метою їх туристсько-рекреаційного використання (огляд) / Н.С. Андрусяк // Науковий вісник Чернівецького університету: збірник наукових праць. Вип. 519-520: Географія. - Ч.: Чернівецький національний університет, 2010. - С. 35-38.

3. Щербань М.Г. Еколого-гігієнічна характеристика проблемних аспектів використання водних рекреацій в Харківській області / М.Г. Щербань, В.А. Капустник, В.В. М'ясоєдов [та ін.]. // Инновационные пути решения актуальных проблем базовых отраслей, экологии, энерго- и ресурсосбережения: сб. науч. тр. - Харьков, 2014. C. $227-235$.

4. Регіональна система організації та контролю оздоровлення населення на рекреаційних водоймах : монографія / М.Г. Щербань, В.В. М'ясоєдов, В.А. Капустник [та ін.]. - Х. : Віровець А.П. «Апостроф», 2014. - $212 \mathrm{c}$.

5. Литвиненко М.I. Еколого-гігієнічне обгрунтування оптимізації регіональної системи рекреаційного використання водойм //Рукопис Дис. Кандидата мед.наук: 14.02.01-Гігієна. К., 2016. - 197 с.

6. Доповідь про стан навколишнього природного середовища в Харківській області за 2019 рік // Державне управління охорони навколишнього природного середовища в Харківській області. - Харків, 2020.

7. Lytvynenko M.I. Ecological and hygienic substantiation of optimization of the regional system of recreational use of reservoirs: author's abstract. dis for obtaining sciences. Degree Candidate medical Sciences: special 14.02.01 «Hygiene and professional pathology» / - Kharkiv, 2016. - 25 p. 